\title{
悪熱帯メソサイクロンのメソ気象学的研究
}

荒川秀俊，渡辺和夫，土屋清，藤田哲也

\section{A Mesometeorological Study of a Subtropical Mesocyclone}

by

\section{Hidetoshi Arakawa}

Tokai University, Hiratsuka, Kanagawa Pref.

\author{
Kazuo Watanabe
}

Meteorological Research Institute, Tokyo

Kiyoshi Tsuchiya

Japan Meteorological Agency, Tokyo

and

\section{T. Theodore Fujita}

The University of Chicago, Chicago

(Received February 22, 1972)

\begin{abstract}
Atmospheric vortices have been classified either according to their horizontal dimensions or to their maximum windspeed. For the purpose of reclassifying them, taking both horizontal dimensions and maximum windspeed simultaneously into consideration, these vortices were located on a maximum windspeed versus diameter diagram (Fig. 1).

When the subtropical mesocyclone of 1 September 1960, which formed over tropical waters and hit Japan the next day (Fig. 2), was placed on this diagram, it was found that the storm in question was located on the border line between the tropical depressions and the mesocyclones.

The mesocyclone was accompanied by arc-shaped echoes around the center and by a curved echo band in the eastern sector far from the center (Fig. 3). The area of composite mesohighs was accompanied by an echo band (Fig. 9). The pressure field of the storm was characterized by a funnel-shaped profile superimposed by an excess-pressure field of the marked mesohigh with a pressure-jump
\end{abstract}


line along its progressive side (Figs. 6 and 7). Due to the fact that most of the squall-line activities took place in eastern sectors of the storm and that the cloud mass encircling the storm center did not grow to the cirrus level, it was characterized by a strictly asymmetric structure (Figs. 8 and 11).

A three-dimensional analysis of the wind field was made by making use of the existing techniques of time-to-space conversions and interpolation for the construction of vertical space cross-section and constant level charts. Results showed that the subtropical mesocyclone was characterized by an overall mass inflow which was about five times larger than that of a large thunderstorm, while it was only about one fifth that of a mature hurricane such as Herricane Daisy of 1958 (Fig. 14).

\section{1. ま}

大気中のじょう乱には，接地境界層内に見られる数センチィートルの渦から惑星波としての 数千キロメートルの長波まで数多くめる。これらじょう乱の分類は主にその水平的広がりの大 きさによって行なわれて来たが，熱帯低気圧だけはとの域内に持続して吹いていると思われる 最大風速によって分類してきた。

そこで, 著者たちは第1図のように，縦軸に地上最大風速をとり，横軸には渦の直径を採る ことによって渦の性質を綜合的に見た。

アリゾナの砂漠に発生するじん旋風の大きさは, SINCIAIR (1965) 飞よると, その影響範 团が渦の中心から $50 \mathrm{~m}$ 以上に及ぶことは注とんどなく，最大風速は50ノット程度，寿命は数秒 といらことである。

水上のたつ巻 (waterspout) とトルネードの小さなものを区別する，はっきりした定義はな いが，前者の多くは暖かい海上で風の水平シャ一の大きな線に沿って現われるよらだし，後者 は雷を伴う激しい対流活動の中で発生する程度の違いになろう。水上に発生するたつ巻に伴う 最大風速は100ノット位までであるらし，影響範囲も $100 \mathrm{~m}$ 以上に及ぶことはほとんどない。

トルネードは自然界に見られる最も激しい渦であり，その最大風速は2 50 ノットあるいはそ れ以上とる考光られている。その影響が $2 \mathrm{~km}$ 以上隹ぶことはむずないであろう。

BROOKS (1949) はトルネードが，それよりひとけたも大きいが風はいたって弱いトルネー ド・サイクロンの中で生じていることを指摘した。このサイクロンの大きさは数キロメートル から数十キロメートルに及ぶこともあり, 最大風速は 50 ノット以下である。

また一般の前線波動として発達する温带低気圧よりも小さくて数百キロメートル以上の大き さに発達することはなく性質る異なる小低気压が存在することがアメリカ国内で10年汪ど前か ら知られるようになり，藤田（1963）は低気圧性循環がまだ現われていないものを mesodepression，低気圧性循環のはっきりしているものを mesocyclone と呼び，この雨者を含めて 一般的に mesolow と称した。

熱帯低気圧 (Tropical cyclone) はその最大風速によって分類されることになって特り，風

注.この論文は1968年にシカゴ大学の Satellite \& Mesometeorology Research Project Report No. 68 として報告されたものを一部改めをた補って和文にしたものである。 


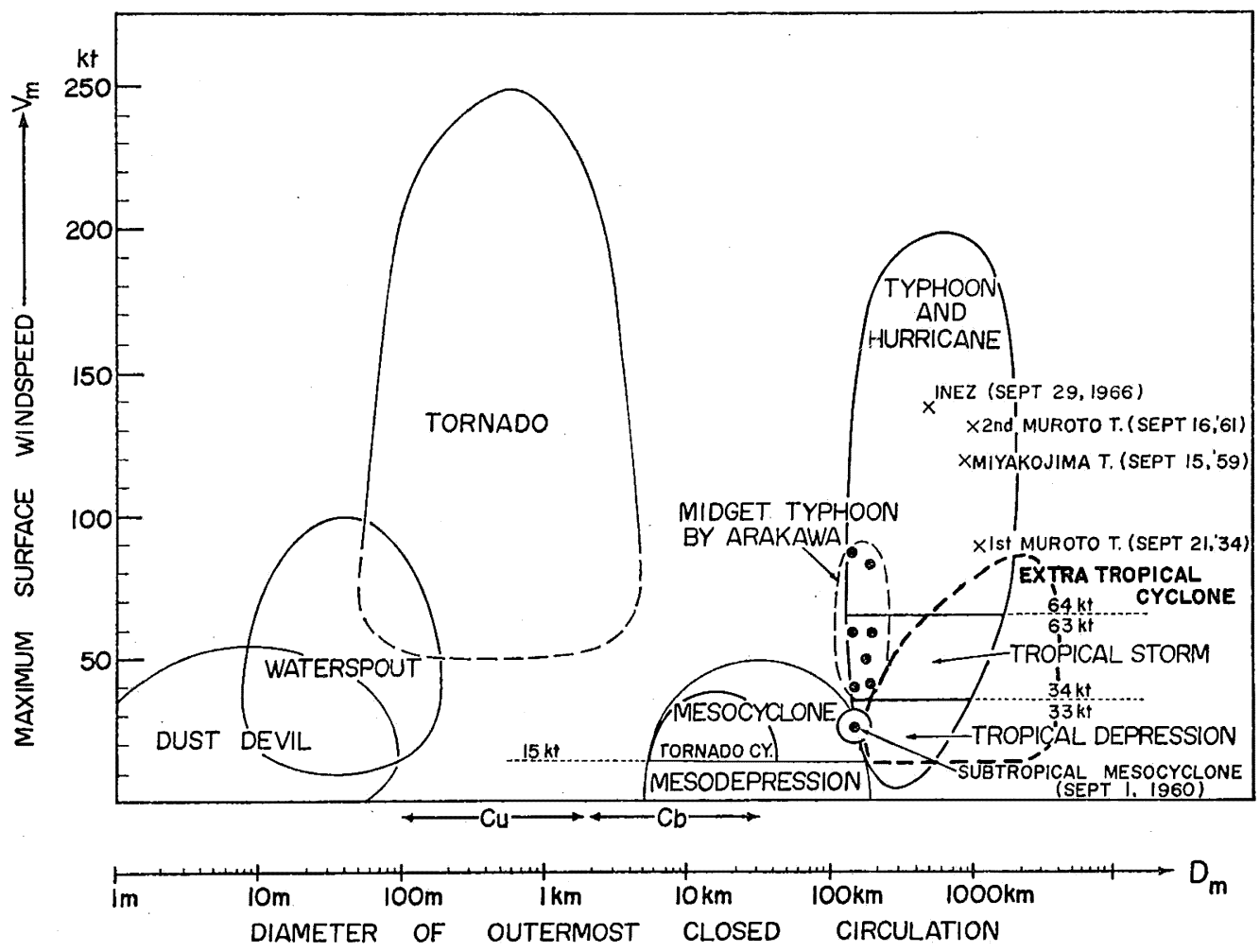

Fig. 1. Characteristic dimensions of meteorological disturbances. The possible range of their maximum windspeed and circulation diameter is outlined for each disturbance. The mesocyclone on 1-2 September 1960 is located on the border line between mesocyclones and tropical depressions.

速33KT以下のものは tropical depression, 34-63KT のものは tropical storm, 64KT 以上 なら typhoon となっている。ところで荒川 (1952) の調査によると, typhoon や tropical storm の暴風を持ちながら渦の規模がきわめて小さな熱帯低気圧があり，豆台風と呼ばれてい る。日本汇近づく豆台風はその一生を通じて直径 $300 \mathrm{~km}$ 越すことはあまりなく，乙かも強風 域は中心附近に限られているので警戒しにくい。7 月から 8 月にかけての盛夏期に沖繩の南海 上や本州の南方洋上が低圧部となる際には，その低圧部の中や東縁に豆台風や弱い熱帯低気圧 が発生しては北上し，日本に影響を与兄ることもある。この種の豆台風の特徵は，比較的高緯 度（主に20度以北）に発生し，その一生を通じて大きく発達しないことである。

熱帯低気圧の発達期に低緯度地方で非常に小型を示す台風があることも知られて扣り，この 種のものは最盛期に入ってから普通の大きさに発達する。HAWKINS (1967)によると, 1966年 9 月28日にアメリカ気象局の観測機はプェルトリコ沖で $175 \mathrm{KT}$ の最大風速を持った小型ハリ ケーンInez 8, $000 \mathrm{ft}$ の高さから観測した。中心気圧は $927 \mathrm{mb}$ と強いハリケーンなのに, 中心 から $90 \mathrm{~km}$ も離れると南側では風速が $30 \mathrm{KT}$ に, 北東側では $46 \mathrm{KT}$ に弱すっていた。地上天気図 に描かれた閉等圧線の大きさも300kmと小さい。そこでHAWKINS は micro-hurricane と名づ けた。Inez は10月 2 日まで小型を保ち，以後は普通のハリケーンのように大型となっている。 


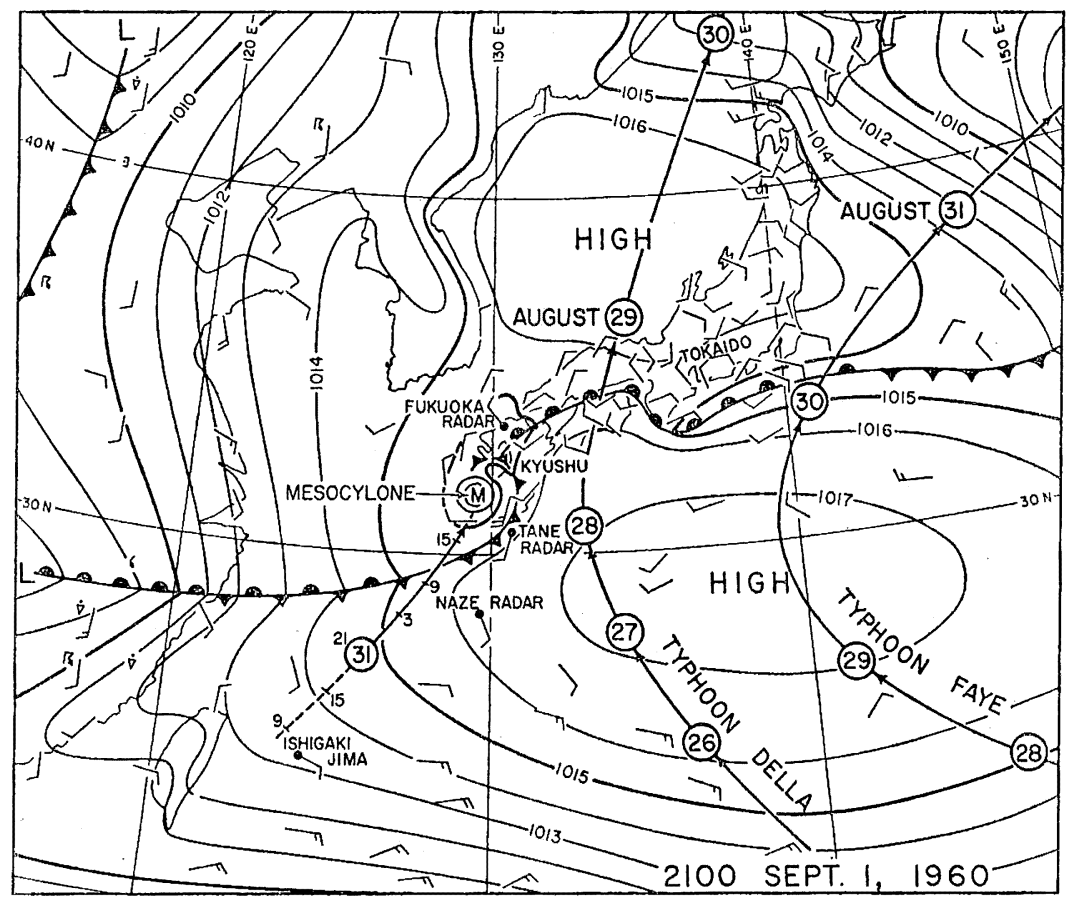

Fig. 2. Surface map for 2100 JST (135E meridian civil time, 1200 GCT) 1 September 1960 . Included in the figure are the 2100 JST position of Typhoon Fay, 28-31 August, Typhoon Della, 26-30 August, and mesocyclone, 31 August-1 September 1960.

1960年 9 月 1 日から 2 日にかけて九州西岸を襲った小じょう乱は, 解析を行なった時点では 既に寒気で报特われて物り，熱帯低気圧とメソサイクロンの中間的性格を持っているところか ら，第 1 図中では亜熱帯メソサイクロンとして分類することとした。SIMPSON (1952) は上 層で発生した切離低気圧が西熱帯や熱帯で作っているじょう乱を亚熱帯サイクロンと称し， RAMAGE (1971) がそれを更にふへんして論じているが，ここで論じようとしている亜熱帯 メソサイクロンとはスケール的にもまた生因的にも別のものである。

次節以下に执いて，この小じょう乱の特徽を解析的に示す。

\section{2. 一 般 概 況}

1960年 8 月31日朝の天気㘡では台湾の東沖に小さな渦が存在するらしい程度にしか分らなか ったが，この渦は北に移動し，翌 9 月 1 日の朝には名瀬のレーダーがこの 渦状エコーを捕え た。この渦状エコーの動きは更に種子島と福岡（脊振山）のレーダーによっても追跡されて 20 時間近くも記録された。

この小じょう乱が九州に近づいた 9 月 1 日夜 (1200GMT) の地上天気図を第 2 図に示す とともに，小じょう乱が発生する数日前に相前後して日本附近を北上していった台風 6016 号 (Della) と6018号 (Faye) の経路と毎日1200GMT の位置を併記した。2 台風が本州の南海上 へ近づくにつれて亜熱帯高気圧は東へ退き，台風が去っためとを再び西へ張りだして来る過程 

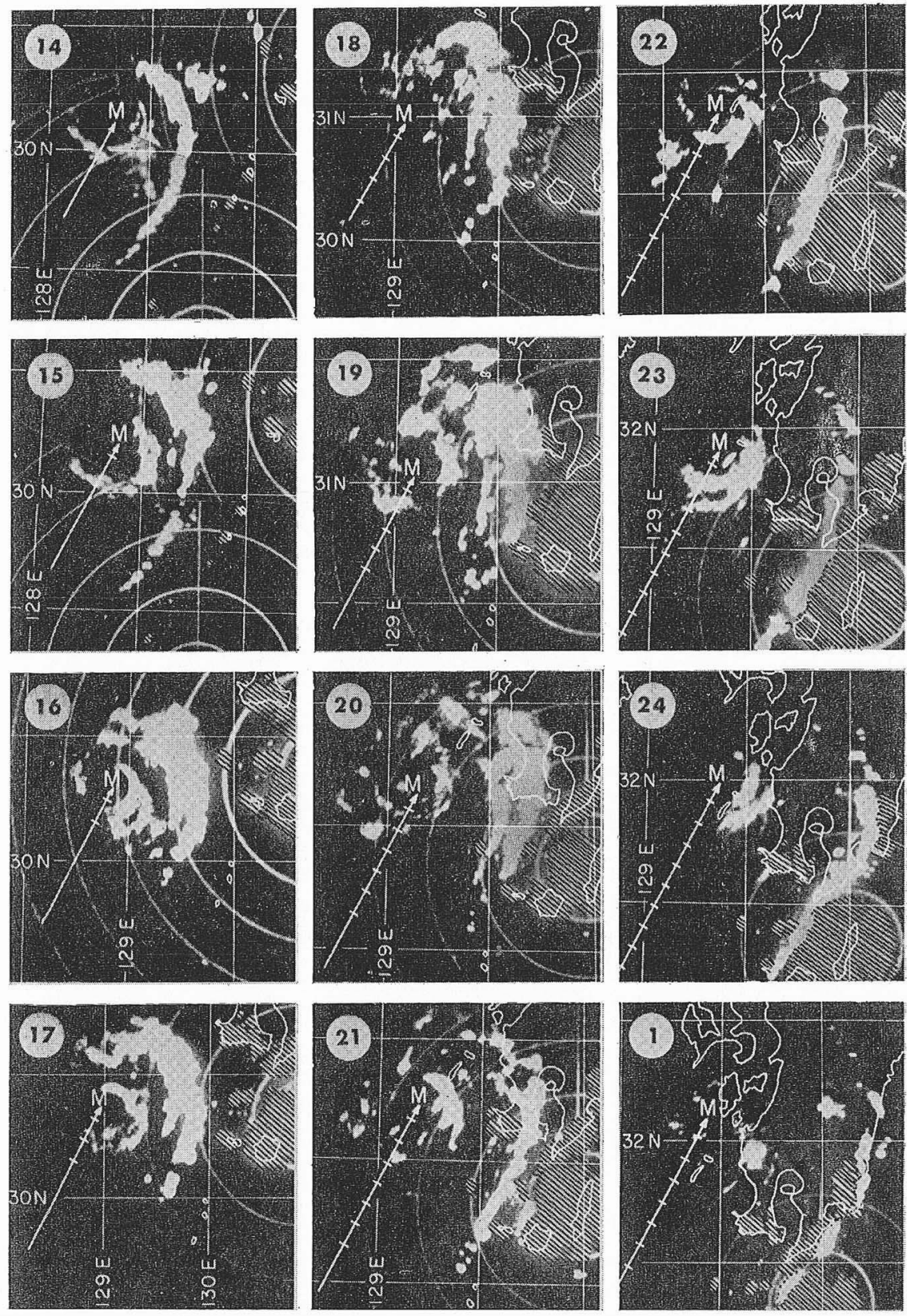

Fig. 3. Hourly composite radar pictures for the period 1400 JST 1 September through 0100 JST 2 September. The areas of apparenti ground clutter are hatched in order to show the precipitation area more distinctly.

で, この小じょう乱怯発生し北東に移動しはじめている。その発生地域は黒潮上で，海面温度 は $28^{\circ} \mathrm{C}$ 以上であった。むた亚熱帯気団の中で発生したと六なされる。

発生の翌日に小じょう乱は弱い停滞前線に接近し，次の24時間には寒気を引きいれて衰弱し 


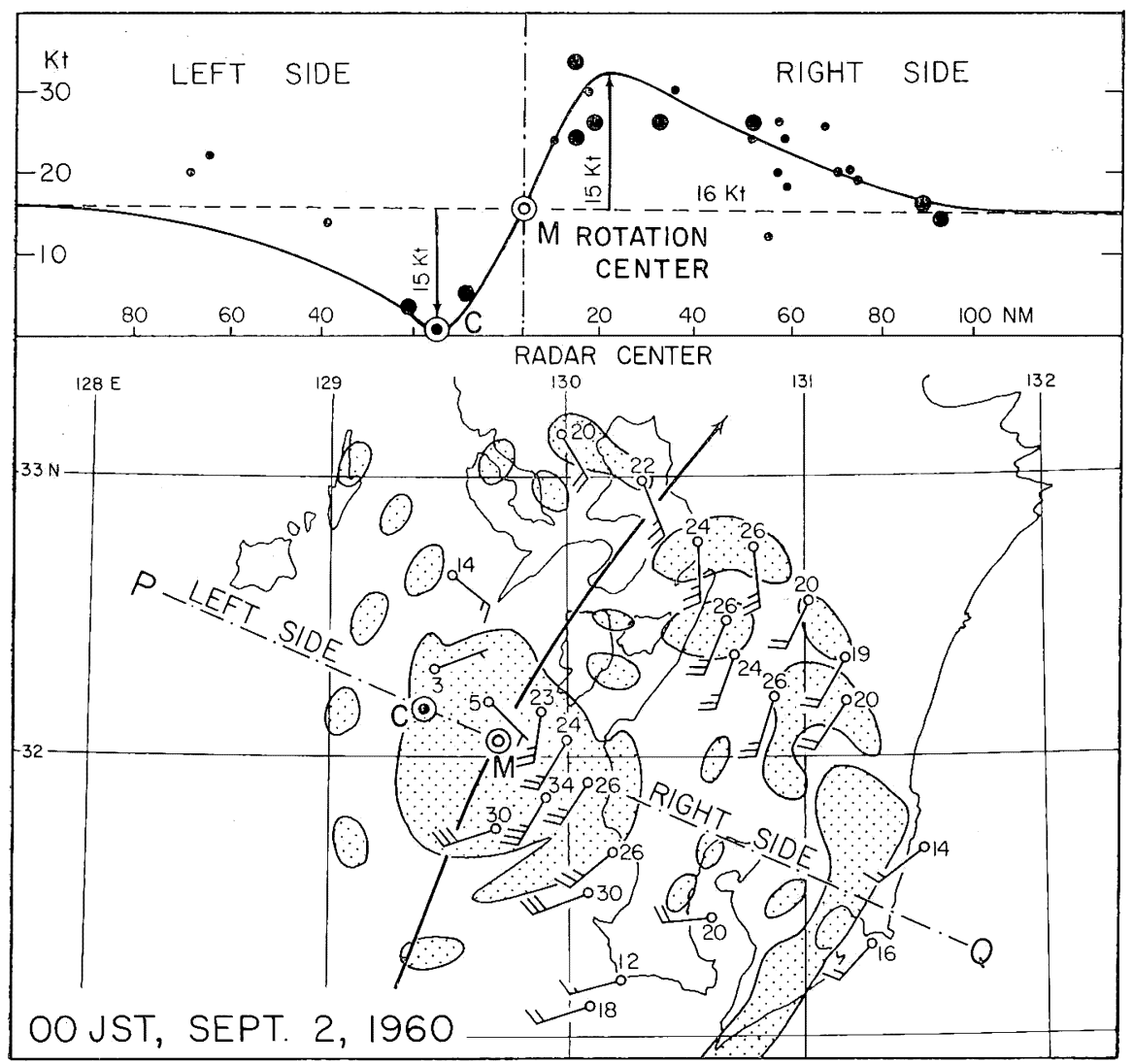

Fig. 4. Echo velocities in knots superimposed upon an echo chart for $0000 \mathrm{JST}$ 2 September 1960. The upper diagram gives the velocity profile along the line $\mathrm{PQ}$ through the mesocyclone center.

ていった。ここで取扱った解析はこの最後の 24 時間についてのものであり，小じょら乱の特徵 とするところのものはメソサイクロンの気圧場に重なる形で顕著なメソ高気圧が存在したこと である。

\section{3. レーダーエコーとその動き}

地方時で 9 月 1 日 14 時から 2 日 1 時にかけての毎時につき作成したレーダー複合写真を第 3 図に示す。各図の中に和ける小じょう乱の位置は “M”の字で示し, それ以前の每時の位置は 経路を横切る短い横線で示している。14時から17洔迄，メソサイクロンの中心部は鮮明な弧状 エコーが半円以上を囲んでいたが，18時以後になると弧状は不鮮明になり，大小バラバラなエ コー群として中心部を取り囲むようになった。

中心部の弧状エコーよりずっと外側に別の螺線状エコーが存在している。この線状エコーは メソサイクロンに侵入して来た寒気の前面に発生したものらしく, 寒気の侵入が進むにつれて 線状エコーは中心部の移動よりも早い速度で外側へと広がっていった。

14 時の複合写真を見ると，外側の線状ェコーより北東に更に $20 \mathrm{~km}$ 潘ど隔れて幾つかのェコ 


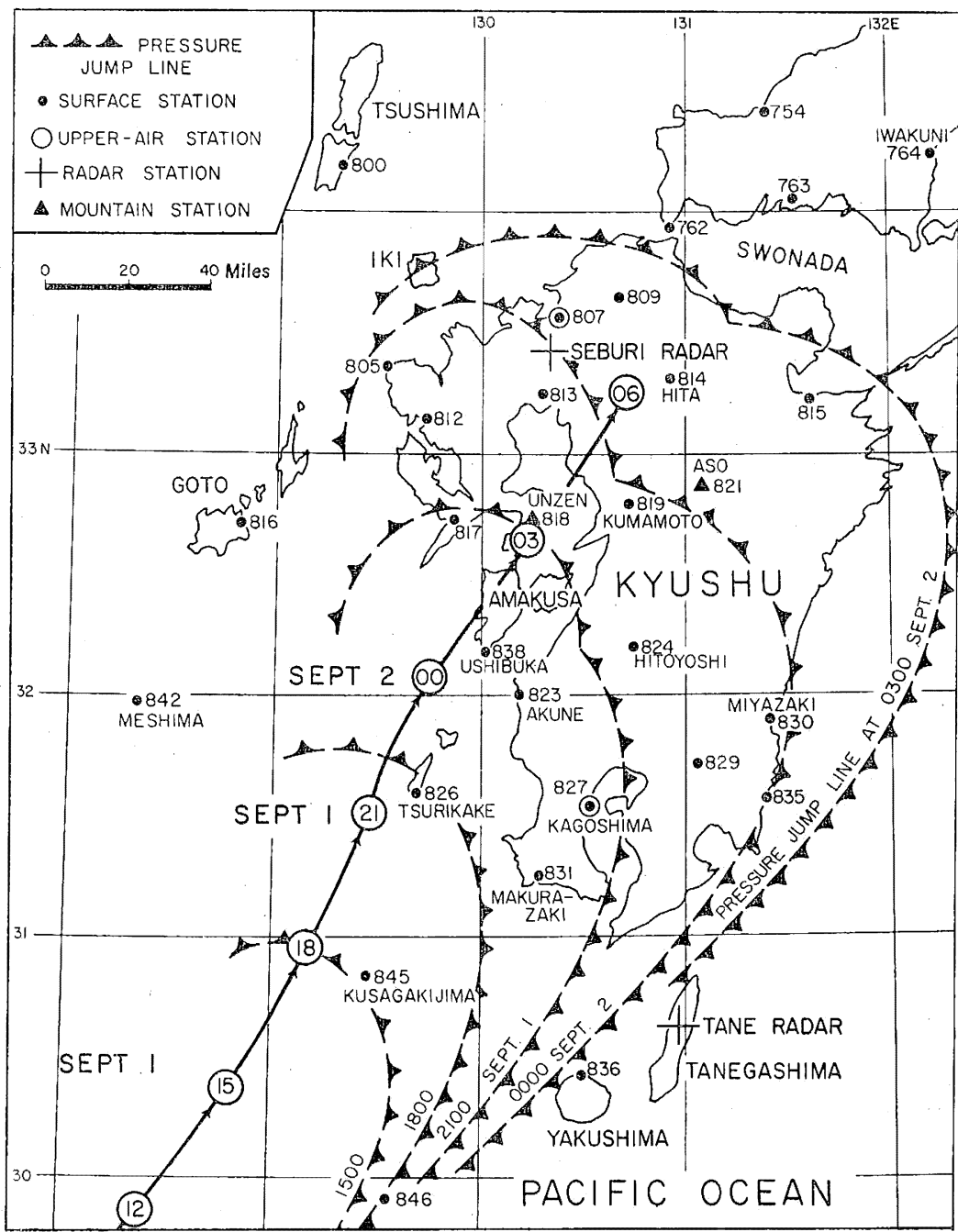

Fig. 5. Positions of the mesocyclone center and the pressure-jump line at three-hour intervals between 1200 JST 1 September and 0600 JST 2 September 1960.

ーが存在している。15時にはこれ等の弧立ニコーと近づいて来た線状ェコーが合併した。16時 から17時にかけては線状エコーが幅広くなると共に，その南端では 2 本の線状エコーに分れつ つあることが示されている。18時から20時にかけての写真では明らかに2本の線状ェコーにな っている。しかし，線状ェコーが九州に入りこむと共に前面の線状エコーは消兄てゆき（21 時)，後側の線状エコーだけが残って22時から 1 時にかけて九州の東岸に存続した。

メソサイクロンが九州の西岸に近づいた 9 月 1 日夜半 (24時) に蛙けるェコーの速度を第 4 図に矢羽根と数值で示した。またメソサイクロンの進行左側と右側でどのようにェコー速度が 変っているか調べたのが第 4 図の上図である。サイクロンの中心を通り，進路に直角に採った 線 PQ 近くで読取ったェコー速度は太丸で記入して大きなウェートを与え，他の象弦で読取 


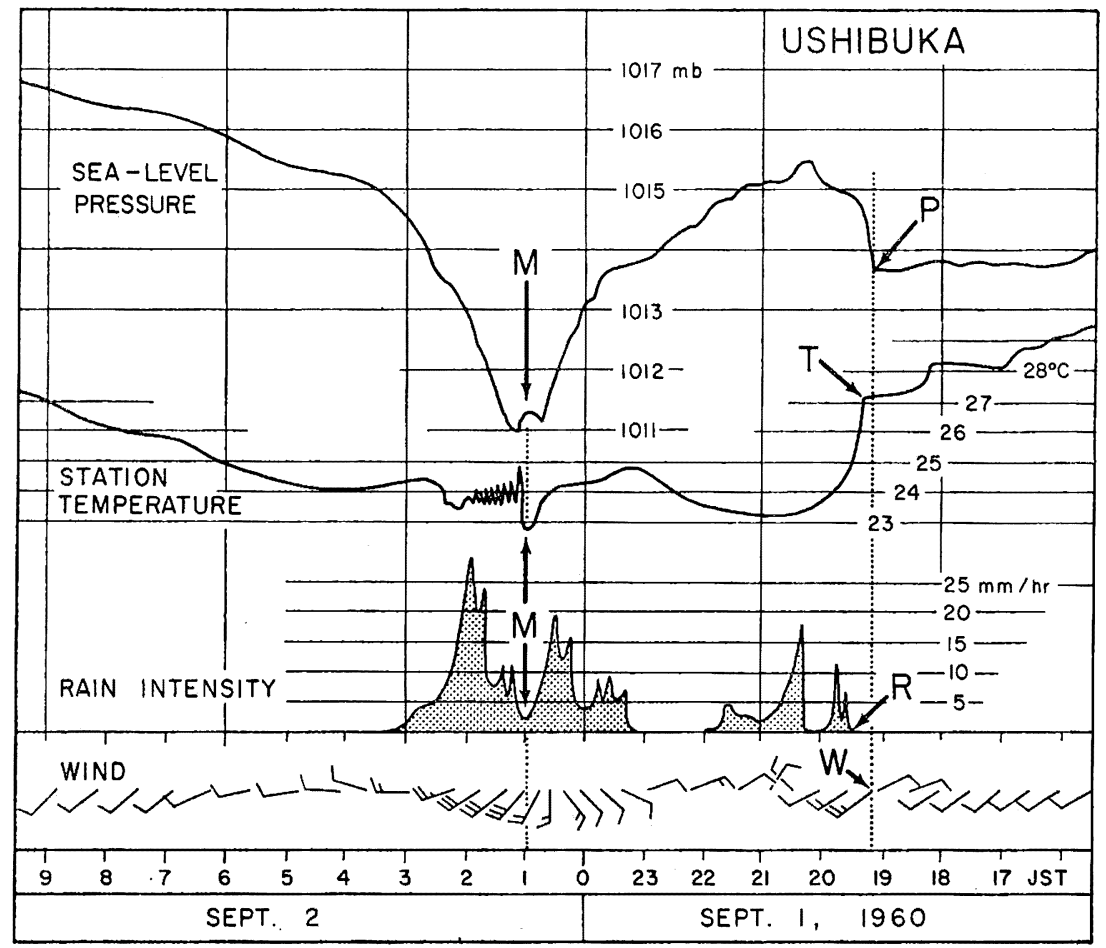

Fig. 6. Change in meteorological elements reduced from the recorded traces at Ushibuka (838), 31m MSL.

った值は小丸で記入して小さなウェートを与兄て考觉ることにした。その左右方向についての エコー速度の分布曲線は，SHAW (1919) が考光た剛体回転をしている正規低気圧が一般気圧 傾度場の中を進む際に表われる回転中心と，トルネードー中心との関係がこのメソサイクロン の場合にも現われていることを示している。ェコー速度の分布曲線は，じょう乱の進行速度 $16 \mathrm{KT}$ 洞の最大速度15KT が組みめわさった形で示されている。

\section{4. メソサイクロンに伴うメソ高気圧}

非常に中心気圧が低い台風の場合とは異り，このメソサイクロンの中心気圧は一般場より 6〜7 mb しか下って招らず，域内の気圧傾度が緩やかなので，域内に括けるメソ気象解析に は非常に度合がよい。

メソサイクロンと気圧急昇線の 3 時間每に叔㺭る位置を第 5 図に示す。気圧急昇線が時と共 に広がっているのはメソ高気圧が発達していることを示するのでめり，その発達をもたらす雷 雨や，にわか雨の状況は第 8 図に示されている。

メソサイクロン独自の気圧場と，めとから派生したメソ高気圧の気圧場との関係を示すのが 第 6 図と 7 図に示す牛深と温泉岳の気象図である。両所は共に経路に当って特り，しかも65km しか離れていないので, 高度 $31 \mathrm{~m} の$ 牛深はメソ高気圧の影響を充分に受けた状態を示し，高度 $852 \mathrm{~m}$ の温泉岳はメソ高気圧の影響を軽く受けた状態を示すと考兄られる 


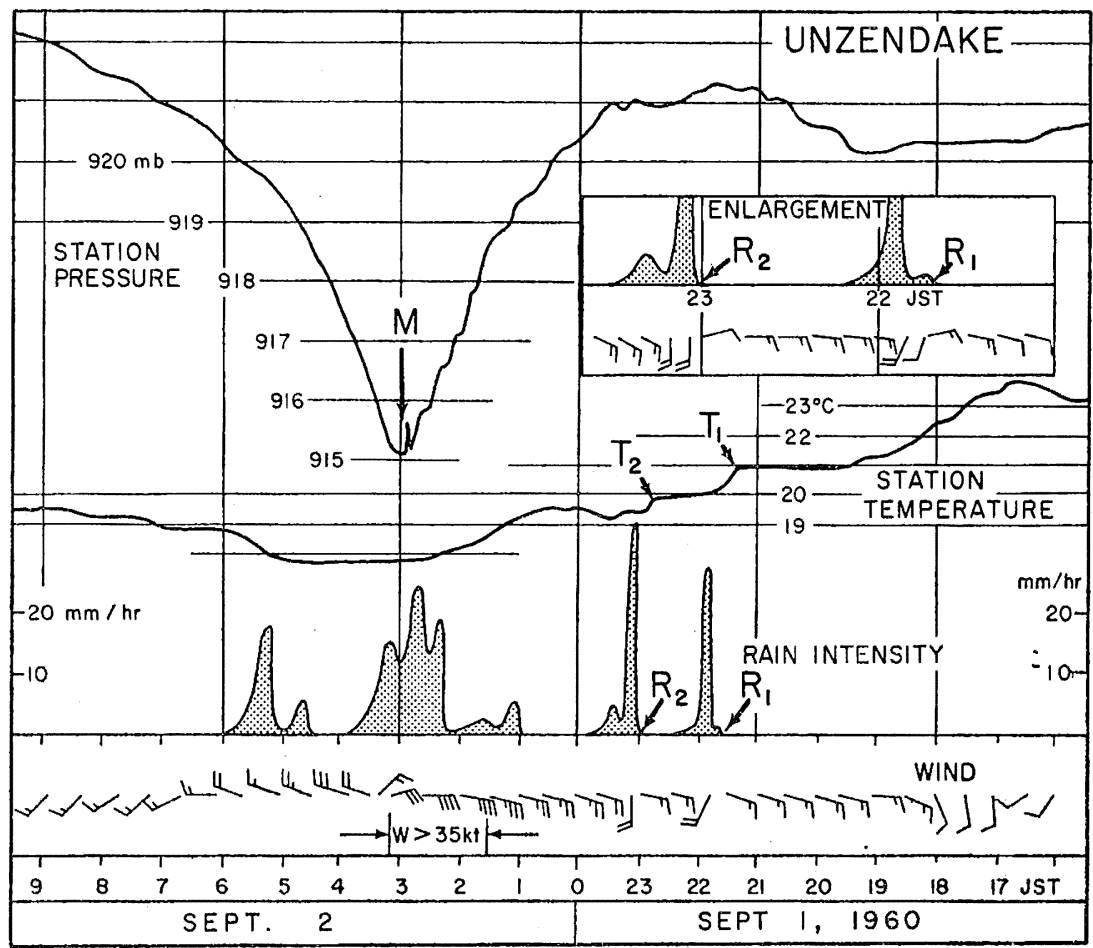

Fig. 7. Change in meteorological elements reduced from the recorded traces at Unzendake (818), 852m MSL.

牛深では 1 日の19時10分に風が ENE から SW に変ると共に $1.2 \mathrm{mb}$ の気圧急昇が現われて 特り，それより10分から15分遅れて気温の低下と降水が現われているが，この時間の遅れは， 一般のメソ的しゅう雨前線について見られるものと同じである。気圧はメソ高気圧の中心部が やって来た時に最高值を示し，その後は下降線をたどって，メソサイクロンの中心が通った 2 日 1 時 0 分に1011 mb の最低値を記録した。降水はメソサイクロンの中心が近づくにつれて強 まり，中心が来た際には一時的に小降りとなり，その後再び強まっている。

温泉岳の気圧と気温の曲線はメソ高気压の影響をあまり示していない。ところが，前節で述 べた第 3 図20時に見られる 2 本の線状降雨帯が温泉岳を通過した 1 日 21 時 50 分と 23 時 10 分頃に 1 時間雨量 $30 \mathrm{~mm}$ 内外の強い降水 $R_{1} \cdot R_{2}$ があり, それに伴って気温の降下 $T_{1}$ と $T_{2}$ があ り，風向にも顕著な変化が示されている。メソサイクロンに吹き込む東北東の風が吹き続いて いたのに，強い降水期間だけ南風がとって代っている。この南風はレーダーエコーの動きとも 一致するものであり，降雨群の中では下降気流が渦の風に置き換っているとみなされる。気圧 が最低に達した 2 日 3 時頃に気温も最も下り, 強い雨が降り続いていたことは, メソサイク口 ンの中心部が既に寒気で満されていたことを示するのであるら。

第 8 図は気圧急昇線と降雨群の間の複雑な関係を示す。図中の太線は 2 日 0 時に特ける 1 時 間に降水のむった地域を示し，細線で $5 \mathrm{~mm}$ 每の等雨量線を，また数值で 1 時間最多降 水量を 示している。雷雨活動はメソサイクロンとは鱓関係にメソ高気圧域で見られ，一般の中緯度地 


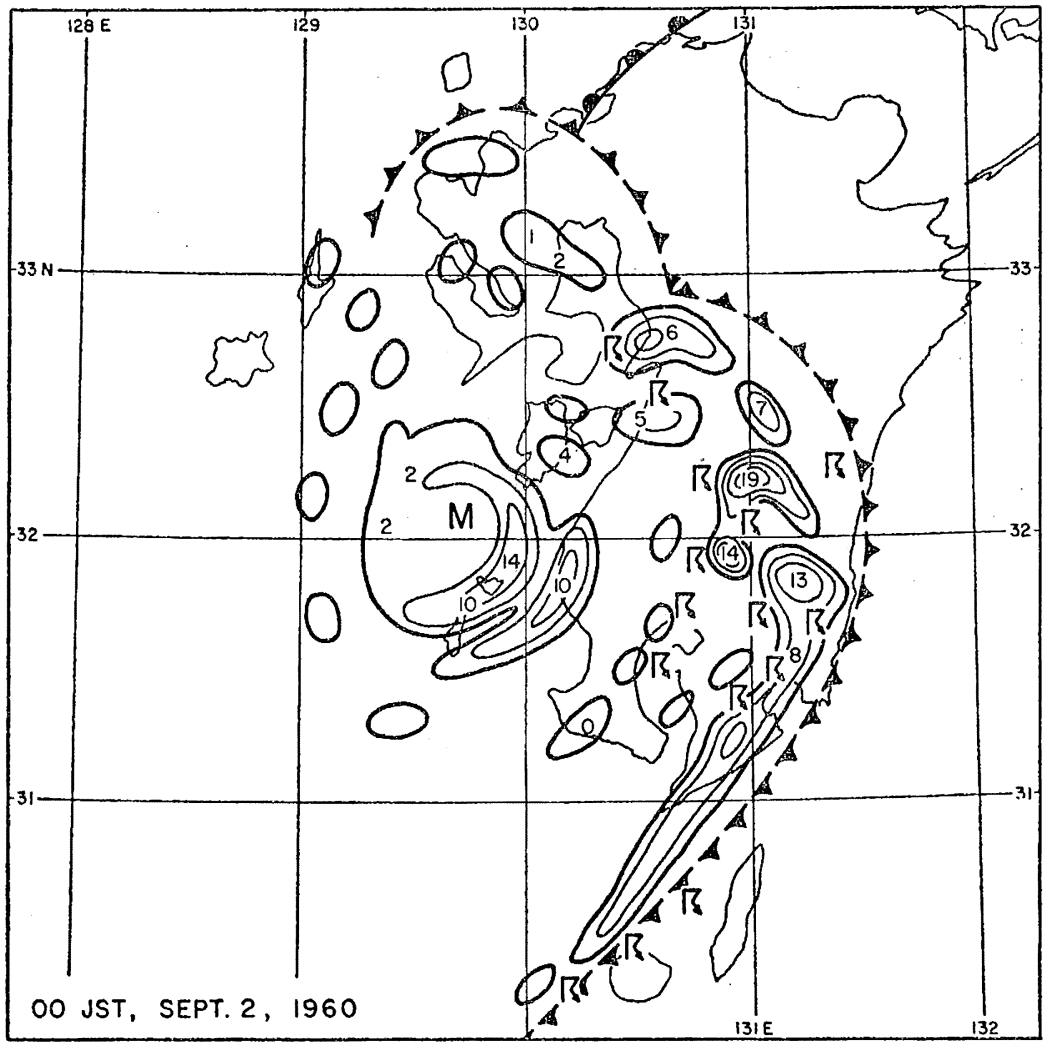

Fig. 8. Hourly precipitation ending at 0000 JST 2 September 1960, contoured by the isohyets at $5-\mathrm{mm}$ intervals. The extreme values in millimeters are given by numbers.

炕見られるメソ高気圧と雷の関係に同じでめる。

第 9 図ではメソサイクロンの図と対比させて，1965年 4 月11日の Palm Sunday に Indiana 州と Michigan 州を荒した幾つかのトルネードを発生させたトルネード・サイクロンの大き さを併記した。トルネード・サイクロンはメソサイクロンよりも一桁小さいようである。メソ

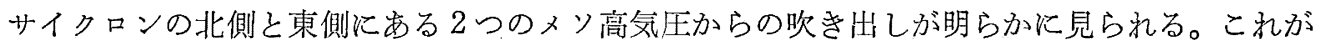
もし台風域内にメソ高気圧が発生していても, 台風の気圧傾度より一桁小さなメり高気圧の存 在やそれからの吹き出し現象はほとんど忍め難いであるう。

\section{5. 風の場の垂直構造}

台風の椿造を調べようとする時には，いつも高層気象観測がそしいことを痛感する。ことに メソサイクロンの場合になると，その影響範囲が台風よりひとけた近く小さいので，高層気象 観測点が少いことは決定的意味を持ってくる。この場合には福岡，麇児島，名瀬，米子で行な った 6 時間每の上層気流観測資料の他に温泉岳の風の每時資料を使い，準定常状態の仮定のも とに藤田（1963）の手法で時間変化を空間変化に值し，また空間内抑をするなどのメり解析技 術でデータ点をふやしていった。 


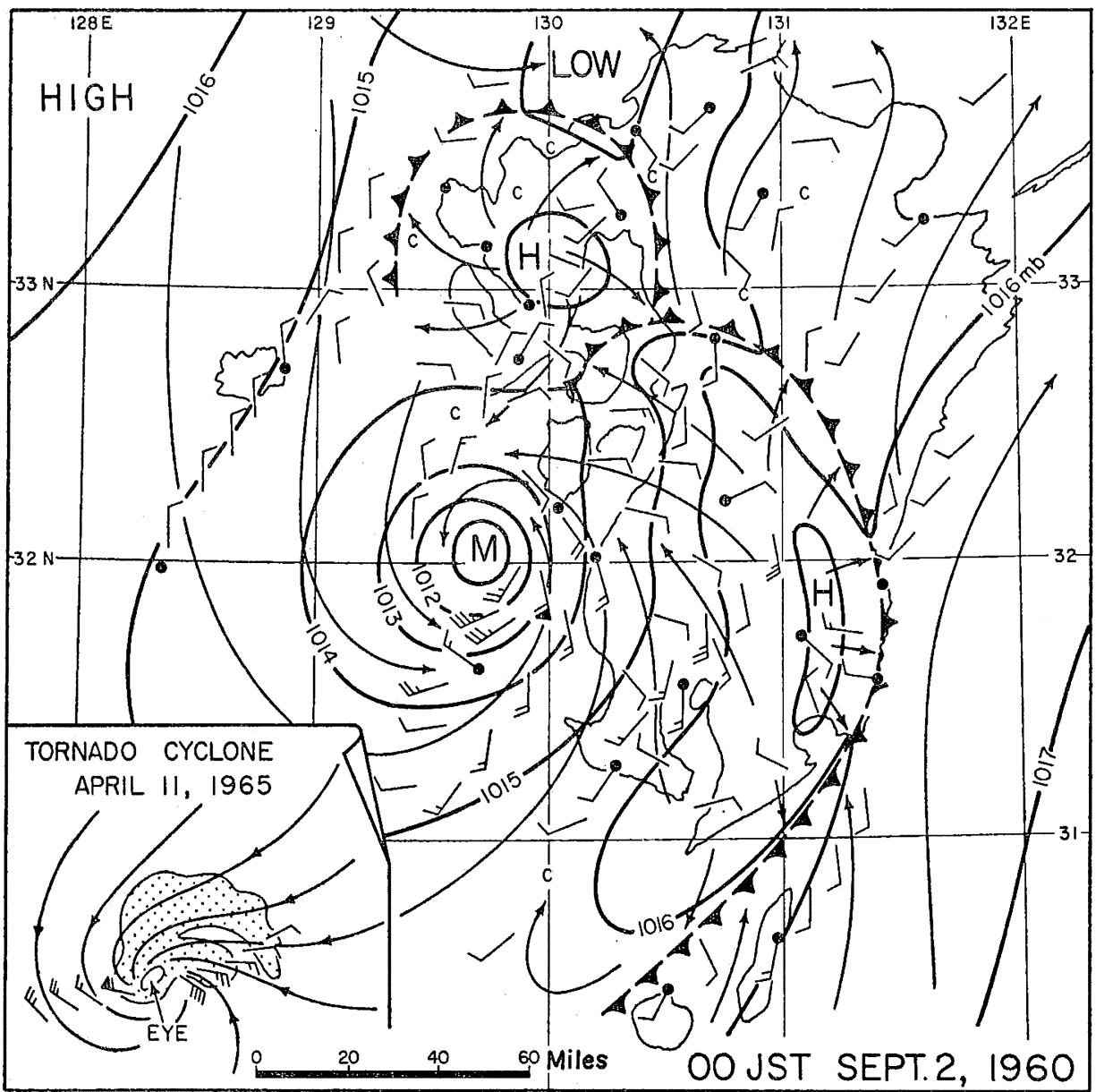

Fig. 9. Stream line field in the subcloud layer at 0000 JST 2 September 1960. The horizontal dimensions of the mesocyclone are compared with those of the tornado cyclone of 11 April 1965 over Michigan.

第10図左上の $1 \mathrm{~km}$ 高度での流線は最大 $34 \mathrm{KT}$ の流入気流を示し，40 度近くの角度でメソサ イクロンに吹き込んでいる。 $3 \mathrm{~km}$ では渦の非対称性がはっきりして物り，7 kmになるともう 渦は認められない。12kmになると吹き出しが顕著になる。12kmにはレーダーェコーの存在部 分を黒く塗り，また等風速線を加えた。この図では流線の間隔は九州から四国・中国に向けて 変っていないので，風速の増加分は主にェコー群からの吹きだしによって補われているとみな せる。メソサイクロンの構造は非対称であり，上層での吹き出しは主に北東方向に行なわれて いるので，メソサイクロンの断面図を作るには，その中心を通り南西から北東に向から面で切 れば，もっともメソサイクロンの特徵を出すことができる。

第11図はそのような面について作った断面図であり，メソサイクロンの進行方向が横軸方向 になっているので，図中に記された矢羽根の方向を60度反時計迴りに回転させたものが真の風 向になる。雲の占める部分は陰影が注どこされており，発散量は破線で示してある。この流れ 


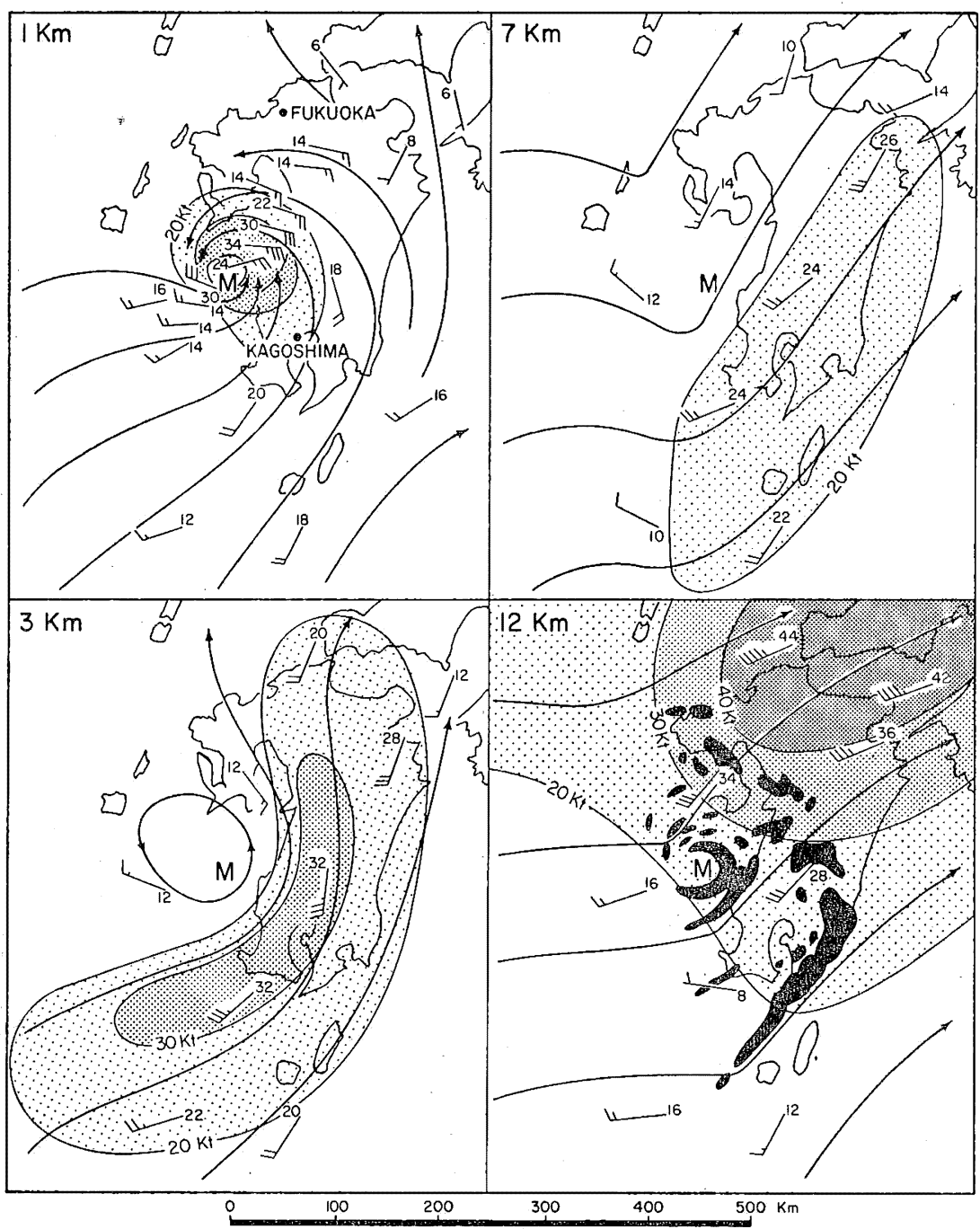

Fig. 10. Upper-air wind patterns at 1,3, 7, and 12-km levels at 0000 JST 2 September 1960. The area of windspeeds above 20,30, and $40 \mathrm{kt}$ are stippled with graduated denser stippling.

の場や発散量の分布にもメソサイクロンの非対称性が表わされている。

\section{3 次元的質量輸送の状態}

台風の 3 次元的質量輸送を調ベるには円筒座標を使い，静力学的釣合を定常状態を仮定して つぎの条件式を使う。

$$
\int_{0}^{H} \int_{0}^{2 \pi} \rho V_{r} r d \theta d Z=\frac{1}{g} \int_{P_{H}}^{P_{0}} \int_{0}^{2 \pi} V_{r} r d \theta d p=0
$$

ここで $\rho$ は空気密度， $V_{r}$ は風の求心成分， $\theta$ は積分すべき角度，Hはメソサイクロン系の頂 




Fig. 11. Vertical cross section of interpolated winds aloft along the track of the mesocyclone. The direction of the wind arrows in the figure were plotted relative to the heading of the mesocyclone, the north-northeast which is shown in the 90 degrees direction (horizontal direction) in the figure. Letters $\mathrm{D}$ and $\mathrm{C}$ in the figure denote the areas of divergence and convergence, respectively.

点部の高さ，Pは気圧とする。

RIEHL と MALKUS (1961) 等は中心からの距離の関数として質量輸送の状沉を気圧高度 $100 \mathrm{mb}$ 毎に求めている。しかし第11図のような断面を持ったきわめて非対称な棈造のメソサイ クロンを扱うのに上記のような方法を採ることは得策でなく，第12図のように円筒を前部と後 部に分けて質量輸送を見ることにした。

メソサイクロンの中心から半径 $200 \mathrm{~km}$ の円を設定し，進行方向について前部と後部に 2 分 すると, 後部への流入 $\bar{A}$, 後部から前部への流入 $\bar{B}$, 前部からの流出 $\bar{C}$ とすれば,

$$
\begin{aligned}
& \bar{A}=\frac{\pi}{6} \operatorname{\rho r}\left(A_{a}+A_{b}+\cdots \cdots \cdots A_{f}\right) \\
& \bar{B}=\frac{1}{3} \operatorname{\rho r}\left(B_{a}+B_{b}+\cdots \cdots \cdots B_{f}\right) \\
& \bar{C}=\frac{\pi}{6} \operatorname{\rho r}\left(C_{a}+C_{a}+\cdots \cdots \cdots C_{f}\right)
\end{aligned}
$$

ここで $\rho$ は高さの関数としての密度とする。

今, 高さ $h-\Delta h$ と $h$ の間にある単位気層 $\Delta h$ についてトームの後部への正味質量流入量は

$$
\Delta R_{h}=\frac{\Delta h}{2}\left\{\left(\bar{A}_{h}-\bar{B}_{h}\right)+\left(\bar{A}_{h-\Delta h}-\bar{B}_{h-\Delta h}\right)\right\}
$$




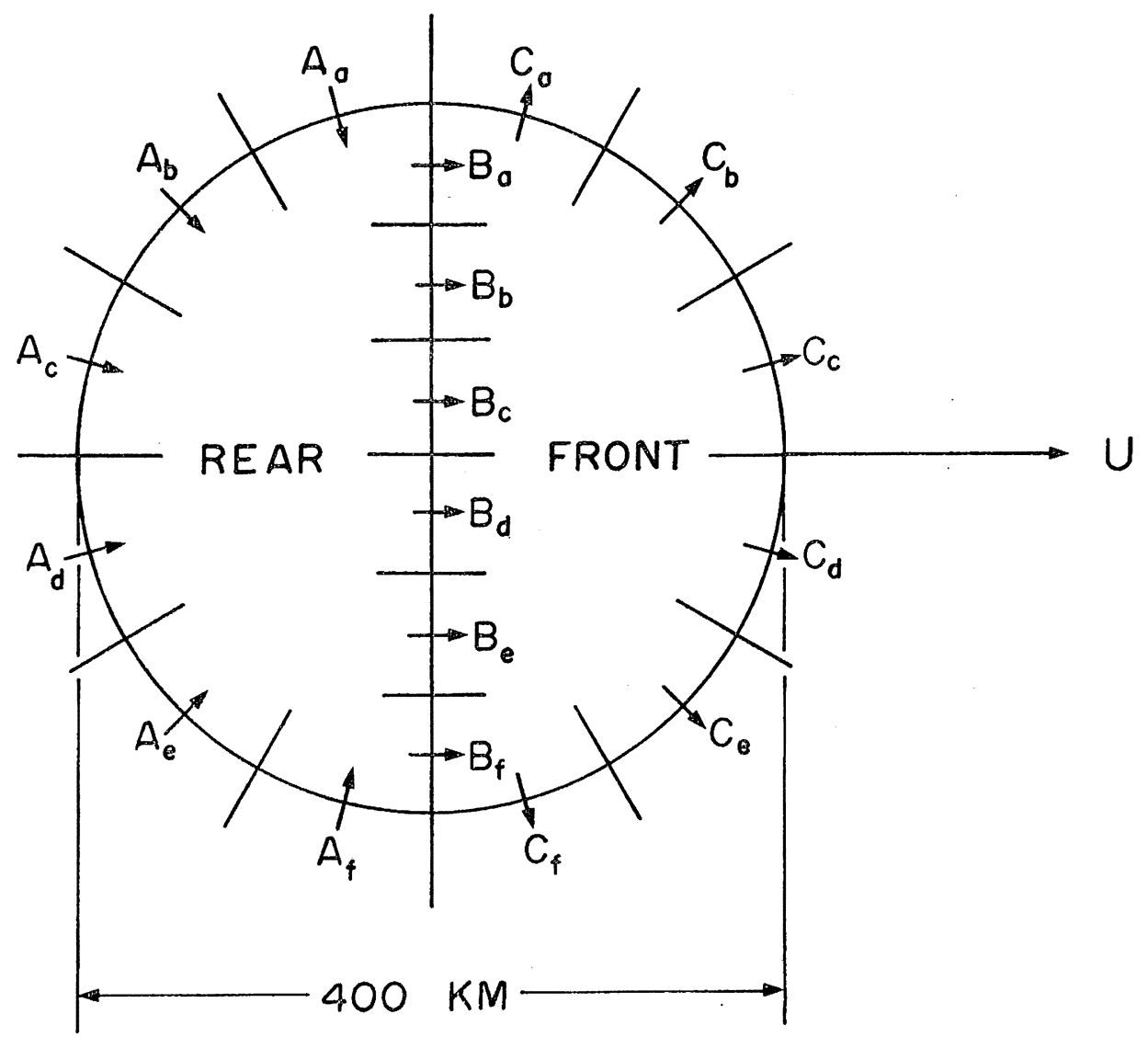

Fig. 12. Components of wind velocities normal to the boundaries of two semi-cylinders of unit thickness to compute the mass fiuxes of the asymmetric mesocyclone. Positive directions of wind velocities $\mathrm{A}, \mathrm{B}$, and $\mathrm{C}$ follow the direction of the arrows. The arrow with the letter "U" denotes the direction of the mesocyclone movement.

同様にしてストームの前部への正味質量流入量は

$$
\Delta F_{h}=\frac{\Delta h}{2}\left\{\left(\bar{B}_{h}-\bar{C}_{h}\right)+\left(\bar{B}_{h-\Delta h}-\bar{C}_{h-\Delta h}\right)\right\}
$$

単位気層 $\Delta h$ を $1 \mathrm{~km}$ に選べば, (2)式と(3)式は

$$
\begin{aligned}
& \Delta R_{h}=\frac{1}{2}\left(\bar{A}_{h}+\bar{A}_{h-1}\right)-\frac{1}{2}\left(\bar{B}_{h}-\bar{B}_{h-1}\right) \\
& \Delta F_{h}=\left(\bar{B}_{h}+\bar{B}_{h-1}\right)-\frac{1}{2}\left(\bar{C}_{h}+\bar{C}_{h-1}\right)
\end{aligned}
$$

この右辺の各項の值は地上から $14 \mathrm{~km}$ 高度まで $1 \mathrm{~km}$ 毎に作った15枚の流線図から求めた。 第13図はこの計算結果をまとめたものであり, 流入は下層後面で大きく, 流出は上層前面で大 きく現われている。 


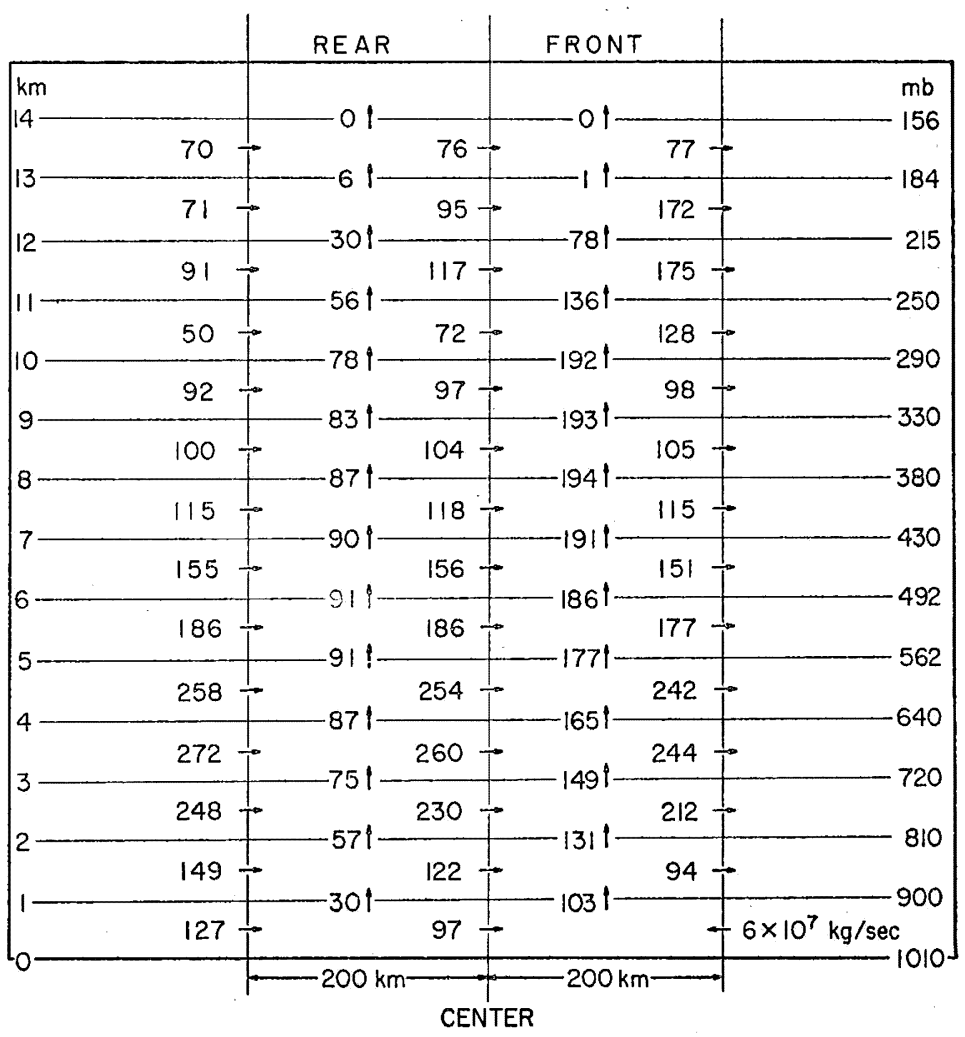

Fig. 13. Horizontal and vertical mass fluxes through the boundaries of the mesocyclone divided into front and rear semi-cylinders. The fluxes are shown for each semi-disc with 1-km thickness. The unit of fluxes is $10^{7} \mathrm{~kg} \mathrm{sec}-1$.

高さ $\mathrm{h}$ の半円筒上面での垂直 flux は， $h$ 上り下にある半円筒についての総流入量に等しい から，前部と後部半円筒についての flux をとれぞれ $F_{h} ， R_{h}$ と寸れば，

$$
\begin{aligned}
& R_{h}=\sum_{1}^{h} \Delta R_{h}=\frac{1}{2} \sum_{1}^{h}\left\{\left(\bar{A}_{h}+\bar{A}_{h-1}\right)-\left(\bar{B}_{h}+\bar{B}_{h-1}\right)\right\} \\
& F_{h}=\sum_{1}^{h} \Delta F_{h}=\frac{1}{2} \sum_{1}^{h}\left\{\left(\bar{B}_{h}+\bar{B}_{h-1}\right)-\left(\bar{C}_{h}+\bar{C}_{h-1}\right)\right\}
\end{aligned}
$$

この計算で求めた垂直 flux の収支も第13図中に記した。矢印の総て上向いているのはたま たま下向きの flux が出てこなかったからである。後面より前面の方が上向きの flux が2 倍 以上も大きな值を示していることも，このメソサイクロンの構造が大きく非対称なことを裏書 きしている。

つぎには，このメソサイクロンへの総質量 flux と, RIEHL と MALKUS (1961) が 1958 年のハリケーン Daisy について求めた質量 fiux を比べよう。同じ条件で比べるために, メ ソサイクロンの中心からの距離20海里から20海里毎に100海里までの圈についての質量 flux を 


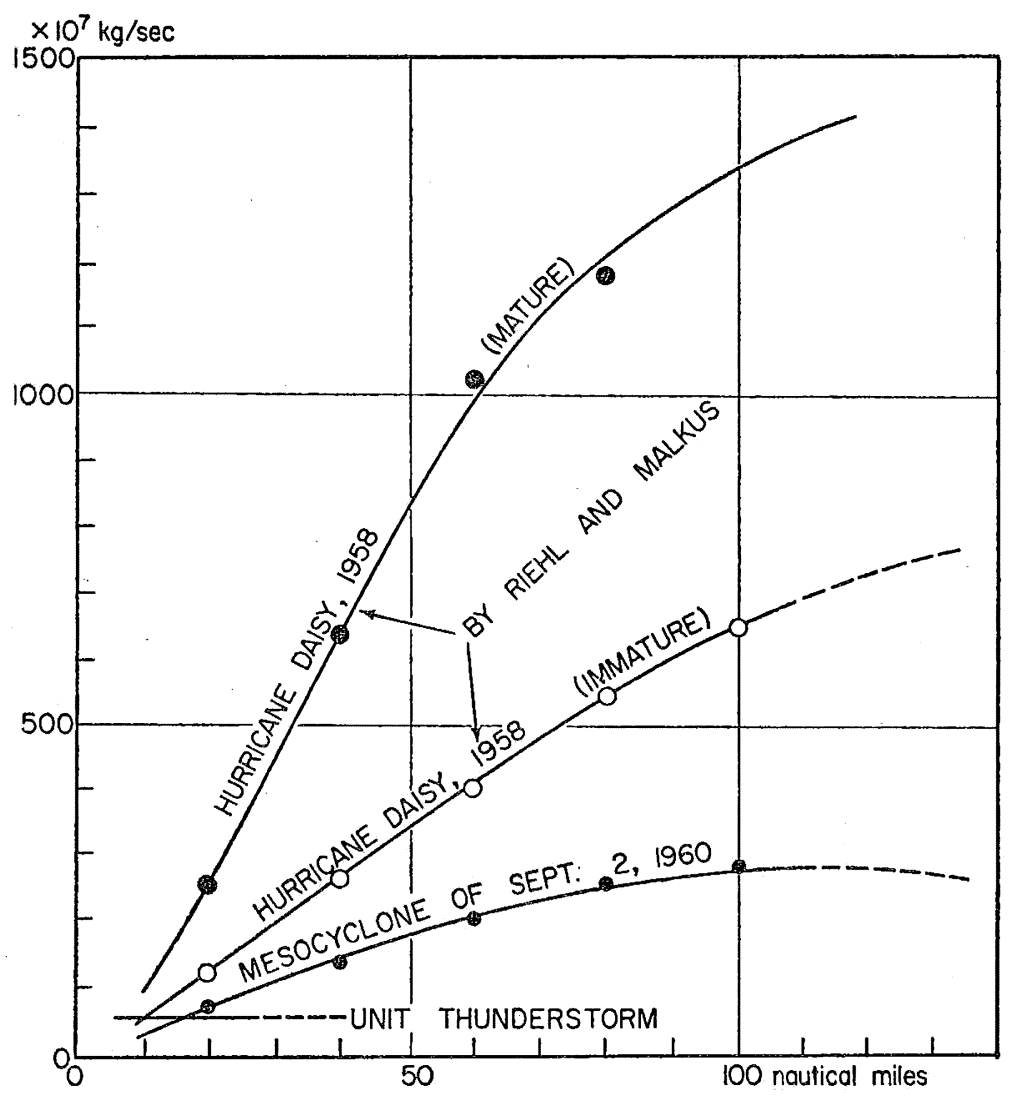

Fig. 14. The total inflow into the mesocyclone and Hurricane Daisy of 1958, computed as a function of the radii from their centers. For purposes of comparison, the inflow of a unit thunderstorm defined in the text is also included in the figure.

求め, ハリケーン Daisy の発達期と最盛期について求められている值とを第 14 図で比較し た。この図から，メソサイクロンへの質量 flux は発達期のハリケーン Daisy の半分量でめ り，最盛期に岁った時の Daisy の1/4に相当していることがわかる。

さらにメソサイクロンへの質量 flux と一個の積乱雲への質量 fiux を比較するために，直 径が $10 \mathrm{~km}$ の積乱雲であり，その $500 \mathrm{mb}$ 高度では每秒 $10 \mathrm{~m}$ の上昇気流があるような単位積乱雲 を想定する。この単位積乱雲へは $50 \times 10^{7} \mathrm{~kg}$ per sec の質量 fiux があることになり，この規 模の積乱雲はかなり強い雷雲に対応するものであろう。メソサイクロンの質量 flux はこの単 位積乱雲の 5 個分, 発達期 Daisy は10個分, 最盛期 Daisy は20個分の単位の積乱雲で代表さ れることになる。

\section{7. 気象衛星から見たメソサイクロン}

メソサイクロンはその小さな規模のために気象観測網にかからないことが多い。そこで気象 

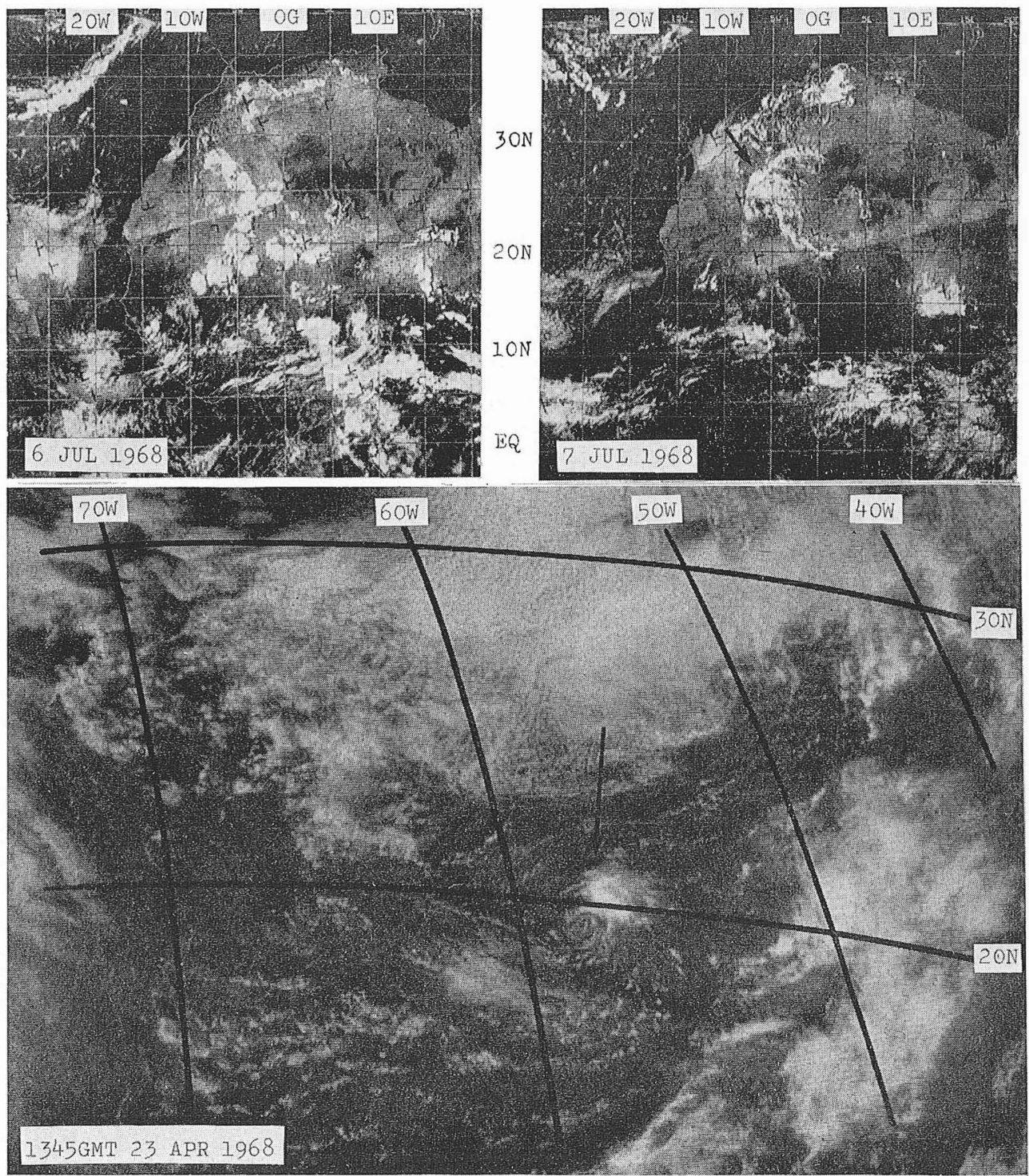

Fig. 15. The subtropical mesocyclones developed over the Sahara Desert on 7 July 1968 (above), and the one in the Atlantic Ocean on 23 April 1968 (below).

衛星が観測した雲の写真を詳細に調べていると，メソサイクロンと思われる小さな雲の渦が数

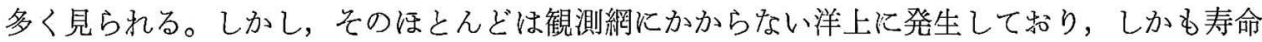
が短いので解析のしようがない。ここで扱った1960年 9 月 1 日から 2 日にかけて九州に上った 亜熱帯メソサイクロンのように詳しく観测記録された例は珍らしいと言えよう。

第15図の上図は1968年 7 月 6 日から 7 日にか将てアフリカのサ八ラ砂漠に発生したハソサイ クロンを示す。6日には不規則な積乱雲の群だったのが翌日には渦を形成し，8日にはモロッ コの近くに達し渦の形を失っている。 
第15図の下図は1968年 4 月23日に大西洋中部で見られたメソサイクロンである。下層の雲は 奇麗な渦を巻いているが, 積乱雲活動と吹き出しは渦の北東側て限られて打り, 全体として非 対称構造を示している。

\section{8. 結 論}

大気中には色々なスケールのじょら乱があり，その岗るものは水平的な広がりでもって分類 され，またあるものは最大風速で分類されて来た。これ等じょう乱を統一的に見るために，本 ず水平的広がりと最大風速の両者を使ってじょう乱を分類しな和してみた。その中には豆台風 というのもある。それは一見したところ Tropical depressionのようであるが，中心部で台台 風の強さを持っている。そのために予報現場に立つ予報官はら線状降雨带を持った小じょら乱 に対しては豆台風の可能性について神経質になる。1960年 9 月 1 日午後に九州へ接近したこの 小じょら乱もら線状ェューを持っていることがレーダーで確認されていたので, 豆台風として 取扱い災害を警戒した。しかし，ここで解析した時点では既に小じょう乱はすっかり寒気内に あり，メソ高気圧に取囲をれていたので，下層の風系やレーダー・エューは渦を示していたが 亜熱帯メソサイクロンとして分類することにした。

メソサイクロンの気圧場は気压傾度が緩いので，気圧急昇線を伴ったメソ高気圧が発達し， メソサイクロンの気圧場を大きく変形してしまった。また積乱雲活動の活とんどは東象获に限 られて岕り，全体としての構造の非対称性が強かった。

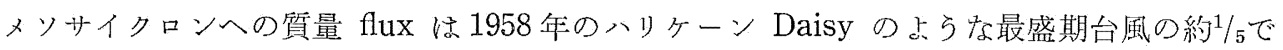
あり，また大きな雷雲 5 個分に相当するもので岗った。

最近は気象衛星でこのよらな小じょう乱を雲の形から検出することができるが，その構造ま でも衛星写真から判断すること㥙困難なので，今後とも1960年 9 月 1 ～ 2 日のメソサイクロン のように，既設観測網によって良く観測記録されたような場合に活，その好機を逃さずに詳し い調査研究を積み上げてゆくことが望なれる。

\section{9. 謝辞}

この研究は「日米科学協力事業」の一つ（GEO-29, Typhoon-5, NSF GF-255) と乙 て行われたものであって，その遂行以岕たっては，文部省，財団法人日本学術振興会，拉よ び米国国立科学財団の協力，援助を得た。また米国環境科学庁からも援助を得た (CWB-E$86-67-G)$ )。厚く感謝する。

\section{References}

Arakawa, H., 1939: Mame-taifu on August 5,1939 (In Japanese). Tenki-to-Kiko, 6, 546-550. , 1952: Mame-taifu or midget typhoon (Small storm of typhoon intensity). Geophys. Mag., 23, 462-474.

Arakawa, H., K. Watanabe, K. Tsuchiya and T. T. Fujita, 1968: A mesometeorological study of a subtropical mesocyclone. SMRP Research Paper, 68, 1-28.

Brooks, E. M., 1949: The tornado cyclone. Weatherwise, 2, 23-33.

Fortner, L. E. Jr., C.L. JoRdan, 1960: A non-tornadic spiral-shaped radar echo. Mon. Wea. Review, 88, 343-348.

Fujita, T., 1963: Analytical Mesometeorology: a review. Met. Mon., 5, 27, 77-125.

Hawkins, H.F. and D.T. Rudsam, 1967: Hurricane Inez - a classic "micro-hurricane". Mariners Weather Log., 11, 157-160. 
Paimen, E. and H. Rierl, 1957: Budget of angular momentum and energy in tropical cyclones. J. Met., 14, 150-159.

Ramage, C.S., 1971: Monsoon Meteorology. Academic Press, NY \& London, 296.

Riehl, H. and J. Malkus, 1961: Some aspect of hurricane Daisy, 1958. Tellus, 13, 181-213.

Shaw, W. N., 1919: Manual of Meteorology. 4, Cambridge Univ. Press, England.

Simpson, R.H., 1952: Evolution of the Kona Storm, a subtropical cyclone. J. Met., 9, 24-35.

Sinclair, P. C., 1965: On the rotation of dust devils. Bull. Amer. Met. Soc., 46, 388-391.

TAKAHASHI, K., 1950 : Distribution of various meteorological elements in a typhoon. J. Met. Soc. Japan, 18, 125-130.

Wexler, H., 1947: Structure of hurricanes as determined by radar. Ann. N. Y. Acad. Sci., 48. $821-844$.

\section{亜熱帯メソサイクロンのメソ気象学的研究}

荒川秀俊, 渡辺和夫, 土屋 清, 藤田哲也

悪熱带性メソサイクロンが各種大気じょら乱の間で占める位置づけをその大きさと強さによって求め たところ，温帯性メソサイクロンと弱い熱带低気圧の中間に在ることがわかった。洋上に発生して，100 $\mathrm{km}$ からせいぜい $200 \mathrm{~km}$ ほどの大きさを持った亜熱帯メソサイクロンを既存の地上観測網で捕捉する機会は きわめて少く，乙たがって，その構造や性質を調べる手掛りはほとんどない。たまたま，1960年 9 月 1 日 のこと,メソサイクロンが東支那海に発生して北東に進んでいることが名瀬レーダーで発見された。それ から一昼夜して，それが九州中部に上陸して消隇するまでの状況をかなり刻明に記録することができたの でこのじょら乱が亚熱帯メソ+イクロンの良い例では決してないが，このケースを調べることによって， メソサイクロンの一般的構造や性質をらかがうことにした。メソサイクロンは亚熱帯じょら乱としての螺 線状降雨帯を持っているが, 中緯度に進んで来ると共に, 収束の大きな東半円内にある降雨带で数多くの 積乱雲が発生して顥著なメソ高気圧を作ってゆく。ところで,じょら乱の主体であるメソサイクロンのス ケールと副産物的なメソ高気圧の大きさと強さが同じオーダーであるために, 後者は前者の構造を著しく 変えてしまうことが特復である。また循環が弱いために対称的構造をとることができず，著しい非対称に なっていることも特徵といえる。

限られた高層観測点と山岳測候所で得られた資料の時系列を使って内挿をほどこし，1 $\mathrm{km}$ から $14 \mathrm{~km} ま$ でを $1 \mathrm{~km}$ 毎に14層の等高度面天気図を作ることによって 3 次元解析を試みた。その結果として, 亜熱帯入 ソサイクロソヘの空気流入量は，巨大積雲のとれと，発達期にある台風への流入量の丁度中間であること がわかった。 